\title{
The 6 Steps of Handwashing Education
}

\author{
Rachmawaty M. Noer ${ }^{1}$, Nurningsih Sinuraya ${ }^{2}$, Septi Maisyaroh Ulina Panggabean ${ }^{3}$, \\ Zulfitri Kadri ${ }^{4}$, Yuni Satriani ${ }^{5}$ \\ 1,4,5 Nursing Science Study Program, STIKes Awal Bros Batam, Indonesia \\ ${ }^{2}$ Tanjung Uban Public Health Centre \\ ${ }^{3}$ S1 Midwifery and Midwifery Professional Education, STIKes Awal Bros Batam, Indonesia \\ ${ }^{*}$ Corresponding Author : \\ Email: rachmawatymnoer1977@gmail.com

\begin{abstract}
.
Washing hands with soap is part of the Clean and Healthy Behavior program in the household. Washing hands with soap is one of the preventive measures through sanitation measures by cleaning the hands and fingers using soap and water. Human hands are often the agents that carry germs and cause pathogens to pass from one person or from nature to another through direct or indirect contact. The purpose of this study was to increase the knowledge and ability to wash hands in community. The activity was carried out on May 06 and May 20, 2021. The method used in this study is lectures and discussions as well as the practice of washing hands through people. The results obtained were increased knowledge of community and the ability to practice washing hands properly.
\end{abstract} \\ video conferencing g. Participants in this activity totaled 20
}

Keywords: Education; Washing Hands; Public

\section{INTRODUCTION}

Washing hands with soap is part of the Clean and Healthy Behavior (PHBS) program in the household. The PHBS program is implemented as an effort to empower household members to be aware, willing, and able to practice clean and healthy living habits. By carrying out the behaviors of carrying out PHBS, the community plays an active role in the health movement in the community such as maintaining and improving health, preventing the risk of disease, and protecting themselves from the threat of disease (Indonesian Ministry of Health, 2009). The United Nations (UN) has designated October 15 as World Hand Washing with Soap Day. These activities mobilize millions of people on five continents to wash their hands with soap. The wider culture of washing hands with soap will make a significant contribution to meeting the Millennium Development Goals (MDGs) target of reducing the mortality rate for children under the age of five in 2015 by around 70 percent.

Washing hands with soap is one of the preventive measures through sanitation measures by cleaning hands and fingers using soap and water. Human hands are often the agents that carry germs and cause pathogens to pass from one person or from nature to another through direct or indirect contact. (Ministry of Health, 2009; Wagner \& Lanoix) According to the Indonesian Ministry of Health (2009), diseases that can be prevented by washing hands with soap are; (1). Respiratory tract infections due to 
washing hands with soap can release respiratory germs found on the hands and the surface of the palms, and can eliminate other germs, (2). Diarrhea due to infectious germs that cause diarrhea is transmitted through the fecal-oral route, so washing hands with soap can prevent transmission of these germs, (3). Worm infections, eye and skin diseases, where studies have proven that apart from diarrhea and respiratory infections, the use of soap in hand washing reduces the incidence of skin diseases, eye infections such as trachoma, and intestinal worms especially for ascariasis and trichuriasis.

Zoonosis or viruses transmitted through animals and humans is the definition of the Corona Virus which has become a pandemic to date. The outbreak of the 2019 corona virus disease (COVID-19) pandemic has caused unrest in various parts of the world (Jannah \& Wulandari, 2020). The widespread social and economic impacts that have occurred have been caused by the transmission of this virus. Coronavirus-19 (COVID) has been declared a world pandemic by WHO.

The disease that we hear more often as COVID 19 is a disease in the respiratory area caused by a type of corona virus. Until now, the number of cases of this corona virus disease reached 1,990,745 people spread across 166 countries, including Indonesia. The prevalence of COVID-19 in Indonesia is quite high. The first confirmed case in Indonesia was on March 2, 2020, where there were only two cases. However, until now the number has reached thousands and puts Indonesia in the first rank of the country infected with COVID-19 in the Southeast Asia region (Sukesih et al., 2020).

Data for 31 March 2020 shows that there are 1,528 cases and 136 confirmed cases of death (Jamaluddin, 2020). COVID-19 or Corona Virus is a new disease that spreads very quickly and has become a pandemic in Indonesia. Based on the results of literature research conducted by Susilo et al (2020) it shows that diseases caused by COVID-19 should be watched out for and not neglected. This is because the transmission of this virus is relatively fast and can cause high mortality. Humans were found to be the main source of spread in the spread of this virus. This spread from one person to another through a liquid (droplet) which comes out when coughing or sneezing (Fatin, 2020).

Prevention of the spread of COVID-19 that has been carried out and introduced by many countries by following WHO guidelines and washing hands is the dominant thing in many cases as a form of early preventive action. Attitude is a reaction or response that is still closed from someone to a stimulus or object (Sari \& Budi, 2018). The attitude and behavior of washing hands because apart from being simple, if done properly when washing hands, they are also considered very efficient in preventing the spread of COVID-19 (Dhiyan, 2020). The PHBS program is a form of providing learning experiences or creating something conducive for individuals. Washing hands with soap ( CTPS) is an indicator of a Clean and Healthy Life Behavior (PHBS). CTPS is defined as one of the sanitation measures by cleaning hands and fingers using soap and water to be clean and is an effort to prevent 
disease. This action is carried out because basically the hand becomes one of the agents that carry pathogenic germs from one person to another (Saida, 2020).

Many changes occurring throughout the world have made several changes to occur in all organisms in the city as a result of this COVID-19 Pandemic. For example, one of them is distance learning which suddenly has to be applied to every education because in Indonesia the learning system dominates using conventional methods. This makes many education providers overwhelmed in providing supervision and delivering learning materials optimally, especially providing early education on maintaining cleanliness to prevent transmission of COVID-19 which is considered quite difficult because there is no direct interaction (Dhiyan, 2020). Distance learning can shorten learning time. In this case, the success of distance learning depends on the process of delivering material and methods from educators.

The proper use of video conferencing during distance learning will be very helpful and have a very good role (Dwi \& Lis, 2020). Based on research conducted by Saida (2020) educational activities conducted online / online via the zoom to explain the importance of handwashing with soap and handsanitizer amid COVID -19 pandemic that dil akukan on June 24, 2020 effective with the results of active participants in education during the discussion session and showed an understanding of the importance of hand washing behavior.

\section{METHODS}

Given that it is still in the period of the Covid-19 pandemic with the implementation of Physical and Social distancing, this activity is carried out online. respondents in this activity were 20 people in Tanjung Uban Village. The stages of this activity consist of:

1. The activity begins with a field survey, the assessment is carried out in Kampung Paya Lebar, Kelurahan Tanjung Uban by making a time contract (date) for the implementation of the activity with the RT head and cadres.

2. Phase $\mathrm{p}$ enyuluhan and demonstrations online

Extension is carried out online with the zoom cloud meeting application, on Thursday, May 6, 2021, 14.00-14.30 WIB with the topic of washing hands properly. Discussion method by providing interactive videos about washing hands to attract people's attention. The video used is a hand washing video from WHO which contains information on how to wash hands properly and correctly using soap and a hands-on sanitizer. In the counseling session, students provide information abouthand washing education which begins with knowing the definition of washing hands, the purpose of washing hands, the right time to wash hands, the benefits of washing hands and how to do hand washing techniques. After that the team provides untu time $\mathrm{k}$ discussion and tany a responsibility to the people who were present at the meeting cloud application zooming and then answer the questions teams. The session continued with the 
screening of hand washing videos which increased the interest and interest of the community to understand about hand washing .

3. Outreach and offline demonstration stage

P enyul uhan done face to face on Thursday, May 20th, 2021 At 15:00 to 15:30 pm with the topic to wash hands properly. The extension method is by doing a handson demonstration of 6 steps hand washing. In the next session, it was to invite residents together to demonstrate the 6 steps of washing hands.

\section{RESULT AND DISCUSSION}

This community service is carried out by 2 (two) students, activities are carried out online and offline. In its implementation, it is the provision of education about hand washing in the form of counseling and exposure to interactive videos related to hand washing and hand washing demonstrations. Interest masyatrakat Service to provide information about washing hands, how to wash hands were either using soap and handsanitizer.

Activities that take place on Thursday, 06 May 2021, 14.00-14 . 30 and Thursday, May 20th, 2021 at 15:00 to 15:30 pm was attended by 20 residents mute Rahan Tanjung Uban. In the stage of providing education in the form of counseling by presenting powerpoints and playing interactive videos about washing hands with soap or hands sanitizer. This activity lasts for 30 minutes and is filled with question and answer sessions and practice as in the following picture .

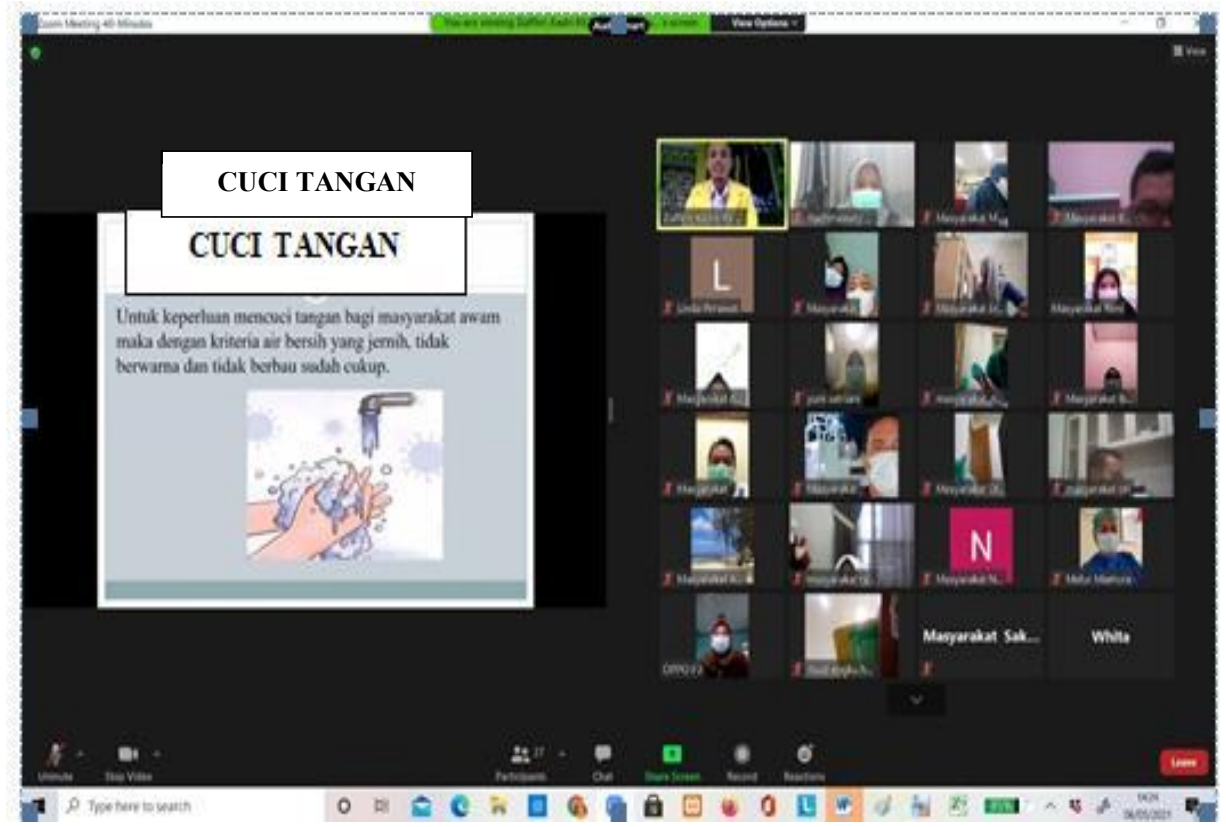

Fig. 1. Handwashing Educational Material Presentation Via Zoom 


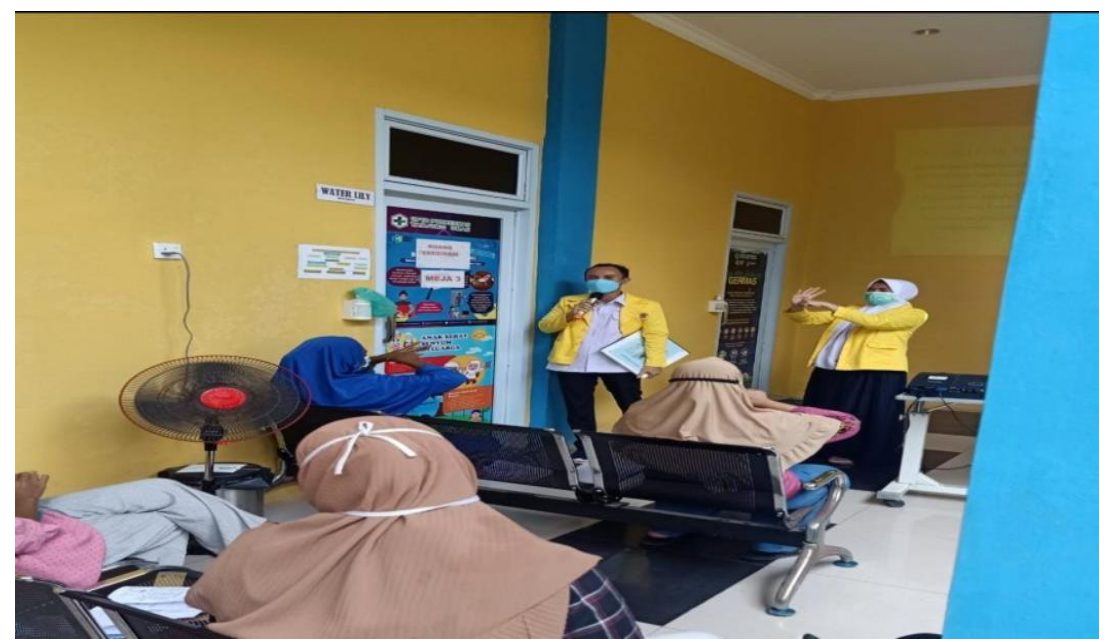

Fig. 2. Handwashing Educational Material Presentation

The profile of nursing graduates have a major role include the implementation of care services (care providers), the manager (manager), educators ( educator), communicant good (comunikator) and with the last level as a researcher ( researcher) (Yuningsih, 2016). Related to their role as educators, nurses are required to be able to increase public awareness of the importance of health through health promotion activities. Through health promotion, nurses can provide education to the wider community related to their health problems (Andanawarih \& Baroroh, 2018).

Health promotion media are all means or efforts to display messages or information that the communicator wants to convey. Health promotion cannot be separated from the media because through the media, the messages conveyed can be more interesting and understood, so that the target can learn more about these messages so that they decide to adopt positive behavior (Papilaya, 2016). There are many health promotion media that can be used, one of which is audio visual as shown in Figure 3 below.

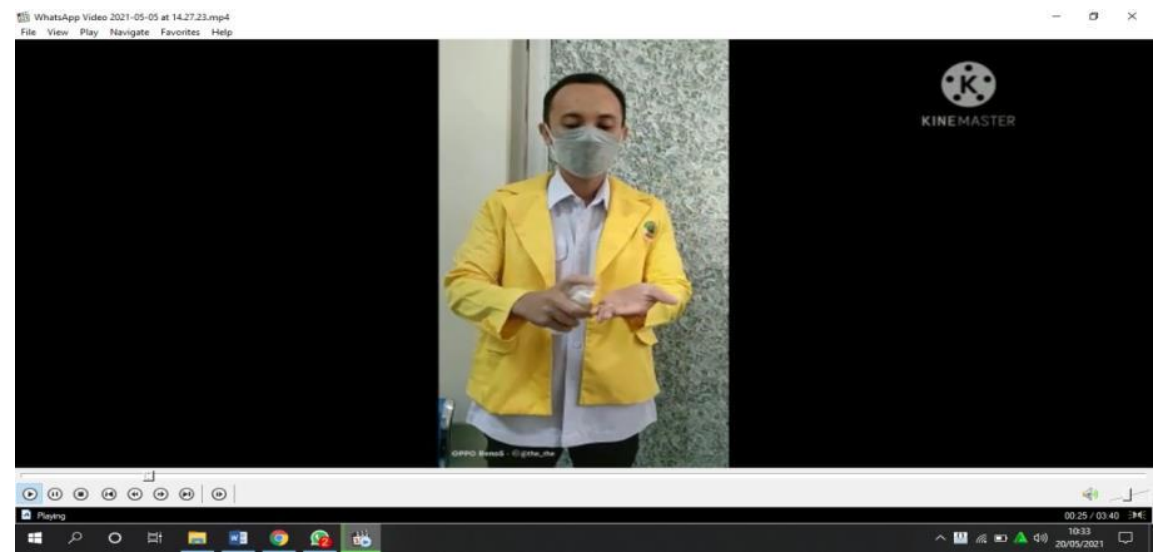

Fig. 3. Hand Washing Video 
Audio visual media is a type of media that in addition to containing sound elements also contains visual elements that can be seen, such as video recordings, sound slides and so on (Dasilva, 2019). The ability of this audio-visual media is considered better and more interesting, because it contains two elements, namely being heard and seen. Through audio-visual media, it is hoped that health promotion will be more effective in increasing knowledge about the importance of washing hands, which includes understanding, benefits, goals, time and a good and correct method for washing hands (Notoatmodjo, 2012).

Health promotion media have the advantage of inviting and providing information to the public about proper hand washing and. Video media can influence people's knowledge and attitudes about the importance of washing hands because these media serve to facilitate the message conveyed by health promoters so that they are conveyed more clearly. Without the use of media, $\mathrm{m}$ aka health promotion become boring and lead the audience out of focus (Kantohe, 2016). The obstacle in this online activity is that there is signal interference from some participants so that the interaction during the activity is not optimal .

\section{CONCLUSION}

Activities carried out on Handwashing Education in Efforts to Prevent Corona Virus through Videos in the community, focused on hand washing education. This service activity is carried out in the form of education, providing materials and practicing washing hands together online with video tutorials. This activity was held based on the findings that many people were unable to wash their hands properly and appropriately during this pandemic. Based on the results of the community service activities that have been carried out, the knowledge of the community in washing hands shows an improvement and can practice it well. With the increased knowledge and ability of students in washing hands, it is hoped that this can prevent the transmission of the corona virus during this pandemic .

\section{ACKNOWLEDGMENTS}

The authors are grateful to the Tanjung Uban Village, STIKes Awal Bros Batam, all of RT 04/RW 07 Tanjung Uban. We also thank preceptors farom STIKes Awal Bros Batam and Tanjung Uban Public Health Centre for the invaluable advices.

\section{REFERENCES}

[1] Dwi, I., \& Lis, P. (2020). Learning Effectiveness Using Video Zoom Cloud Meeting in Early Childhood in the Covid-19 Pandemic Era. Journal of Early Childhood Education, 667.

[2] Fatin. (2020). Making Simple Handwashing in Red Zone Local Communities as a Prevention Step for the Spread of COVID-19. Journal of Community Service, 641. 
[3] Jamaluddin. (2020). National Disaster Response Efforts through Education and Prevention of the Spread of Covid-19 in the City of Baubau. Journal of Medical Service, 40 .

[4] Saida. (2020). Prevent Covid 19 through Education on Clean and Healthy Living Behavior in Puwatu District, Kendari City. Journal Of Community Engagement in Health, 330 .

[5] Sari, DNA, \& Budi, S. (2018). The Relationship between Spiritual Quoitient and Sexual Attitudes of Prisoners. Al-Irsyad Health Journal , XIII (2), 227-234.

[6] Sukesih, Usman, Budi, S., \& Sari, DNA (2020). Knowledge and Attitudes of Health Students on Prevention of COVID-19 in Indonesia. Journal of Nursing and Midwifery, 11 (2), 258-264.

[7] Susilo, A., Rumende, CM, Pitoyo, CW, Santoso, WD, Yulianti, M., Herikurniawan, H., Sinto, R., Singh, G., Nainggolan, L., Nelwan, EJ, Chen, LK, Widhani, A., Wijaya, E., Wicaksana, B., Maksum, M.,Annisa, F., Jasirwan, COM, \& Yunihastuti, E. (2020).Coronavirus Disease 2019: A Review of Recent Literature. Indonesian Journal of Internal Medicine , 7 (1), 45. https://doi.org/10.7454/jpdi.v7i1.415

[8] M. Christiansen, E. Baadsgaard, J. Sanyova, K. Simonsen, The artists' material of P.S. Krøyer: An analytical study of the artist's paintings and tube colours by Raman, SEMEDS and HPLC, Heritage Science, 5, 2017, pp. 39-50.

[9] N. Khandekar, E. Nagy, J. Miller, P. Gottschaller, C. Mancusi-Ungaro, The rerestoration of Donald Judd's 'Untitled, 1965', Modern Paints Uncovered (Editors: T.J.S. Learner, P. Smithen, J.W. Krueger, M.R. Schilling), First edition, Getty Publications, Los Angeles, 2007, pp. 157-164.

[10] S. Lomax, S. Fisher, An investigation of the removability of naturally aged synthetic picture varnishes, Journal of the American Institute of Conservation, 29, 1990, pp. 181-191.

[11] M.T. Doménech-Carbó, M.F. Silva, E. Aura-Castro, A. Doménech-Carbó, L. FusterLópez, J.V. Gimeno-Adelantado, S.U. Kröner, M.L. Martínez-Bazán, X. Más-Barberá, M.F. Mecklenburg, L. Osete-Cortina, D.J. Yusá-Marco, Multitechnique approach to evaluate cleaning treatments for acrylic and polyvinyl acetate paints, in: New insights into the cleaning of paintings (editors: M.F. Mecklenburg, A.E. Charola, R.J. Koestler), Smithsonian Institution Scholarly Press, 2013, pp. 125-134.

[12] S. Tsuge, H. Othani, C. Watanabe, Pyrolysis - GC/MS Data Book of Synthetic Polymers, First edition, Elsevier, 2011, p. 420.

[13] J. Hayes, M. Golden, G.D. Smith, From formulation to finished product: Causes and potential cures for conservation concerns in acrylic emulsion paints, Modern Paints Uncovered (Editors: T.J.S. Learner, P. Smithen, J.W. Krueger, M.R. Schilling), First edition), The Getty Conservation Institute, Los Angeles, 2007, pp. 58-65.

[14] V.R. Sastri, Applications, Modern Aspects of Rare Earths and Their Complexes (Editors: V.R. Sastri, J.C. Bünzli, V. Ramachandra Rao, G.V.S. Rayudu, J.R. Perumareddi), First edition, Elsevier, 2003, pp. 893-981. 